\title{
Identification and effectiveness of rhizobial strains that nodulate Lupinus polyphyllus
}

\author{
T.P. RYAN-SALTER, A.D. BLACK, M. ANDREWS and D.J. MOOT \\ Department of Agricultural Sciences, PO Box 85084, Lincoln University, Lincoln 7647, Christchurch \\ travis.ryansalter@lincolnuni.ac.nz
}

\begin{abstract}
Lupinus polyphyllus plants were heavily nodulated at 10 field sites sampled across the South Island. Twenty-two bacterial isolates from these nodules formed functional nodules on $L$. polyphyllus indicating that rhizobia that nodulate $L$. polyphyllus were present across a wide range of sites in the South Island. Gene sequences identified all 22 isolates and the Group G commercial inoculant as Bradyrhizobium. Eleven isolates and the Group $\mathrm{G}$ inoculant were tested for their effectiveness on growth of L. polyphyllus plants in a high country soil in a glasshouse. All plants nodulated regardless of inoculum treatment but there was variability in effectiveness. This suggests that it may be beneficial to use a rhizobial inoculant for high country soils, but further work is required before a recommendation can be made.
\end{abstract}

Keywords: nitrogen fixation, perennial lupin, Lupinus polyphyllus

\section{Introduction}

Wild populations of the perennial legume Lupinus polyphyllus have colonised roadsides and riverbeds throughout the South Island of New Zealand. Originally introduced as a horticultural garden species, $L$. polyphyllus and its variants (hybrids of L. polyphyllus with several other lupin species; also known as Russell lupins) were valued for their colourful flowers. However, garden escapes and deliberate spreading on bare roadside soils have caused proliferation of the species within the Mackenzie Basin and Arthur's Pass regions. More recently, L. polyphyllus has been shown to have potential as a forage plant in extensive high country grasslands (Black et al. 2014; Scott 2014).

As with most legumes, L. polyphyllus is capable of fixing atmospheric nitrogen $(\mathrm{N})$ via symbiotic bacteria ("rhizobia") in root nodules. This ability can give legumes an advantage under low soil $\mathrm{N}$ conditions if other factors are favourable for growth (Andrews et al. 2011, 2013). Annual lupin species (e.g. L. angustifolius) are generally nodulated by rhizobia strains belonging to the slow-growing, acid-tolerant Bradyrhizobium genus (Jarabo-Lorenzo et al. 2003; Weir et al. 2004).
Commercial inoculants that contain Bradyrhizobium sp. have been developed for annual lupins, and have also been recommended for use on $L$. polyphyllus (Scott 1989). However, no attempt has been made to select rhizobial strains for use as an inoculum on $L$. polyphyllus, or to identify the range of rhizobia that nodulate our current populations.

The objectives of this study were to 1) determine if L. polyphyllus is nodulated over a wide range of sites throughout the South Island of New Zealand, 2) genotypically characterise the rhizobia that nodulate L. polyphyllus in the South Island, and 3) assess if there is variability in effectiveness of these rhizobia on growth of L. polyphyllus in a high country soil. This final objective will determine whether the use of a commercial inoculant is necessary in high country soil.

\section{Methods}

\section{Bacterial isolates}

Twenty-two rhizobial isolates were obtained from nodules of different $L$. polyphyllus plants sampled from four sites at Arthur's Pass (AP; 11 isolates), three sites in the Mackenzie Basin (MB; six isolates), two sites in Central Otago (CO; three isolates) and one site near Te Anau (TA; two isolates), South Island, New Zealand in March 2013 (Table 1). All isolates were obtained from wild roadside populations of L. polyphyllus except for two isolates that were obtained from an agricultural stand at Sawdon Station, near Lake Tekapo, in the Mackenzie Basin. A further isolate was obtained under sterile conditions from L. polyphyllus plants supplied Group $\mathrm{G}$ inoculant, recommended for annual lupins (Becker Underwood).

Root nodules were surface sterilised by immersion in $96 \%$ ethanol for $5 \mathrm{~s}$ and $0.5 \%$ sodium hypochlorite for $3 \mathrm{~min}$ and then were rinsed with sterile water. Surfacesterilised nodules were crushed in sterile water, and this suspension was streaked onto yeast mannitol agar (YMA) (Vincent 1970) and incubated at $20^{\circ} \mathrm{C}$ in the dark for 2-4 days. A purified culture was obtained by repetitive subculture. Samples of all cultures were inoculated into a suspension of yeast mannitol broth (YMB) (Vincent 1970) and used for preparation of DNA or inoculum. 


\section{Gene sequencing and phylogenetic analyses}

DNA was extracted from the bacterial cultures using the standard Gentra PUREGENE Purification Kit (Qiagen) following the protocol for gram-negative bacteria. Two genes were sequenced: the small subunit ribosomal RNA (16S rRNA) and N-acyltransferase nodulation protein A $(\operatorname{nod} A)$. The $16 \mathrm{~s}$ rRNA and nodA primers used were those described in Weisburg et al. (1991) and Chaintreuil et al. (2001) respectively. Both primers were manufactured by Integrated DNA Technologies, Auckland, New Zealand.

All PCR amplifications were performed using the FastStart $^{\mathrm{TM}}$ Taq DNA Polymerase kit (Roche Applied Science, Auckland) optimised for annealing temperature and primer concentrations. The PCR products were resolved via gel electrophoresis $(1 \%$ agarose gel in $1 \times$ Tris-acetate-EDTA buffer) followed by staining with ethidium bromide and viewing under UV light. PCR products were sequenced by the Biological Protection Research Centre Sequencing Facility, Lincoln University. DNA sequence data were obtained via Sequence Scanner v 1.0 software (CApplied Biosystems) and were edited and assembled using DNAMAN Version 6 (CLynnon Biosoft Corporation).

DNA sequences were aligned and Maximum Likelihood trees constructed with 500 bootstrap replications with partial deletion and $80 \%$ coverage cut off using MEGA6 software (Tamura et al. 2007). Only bootstrap values $\geq 50 \%$ are shown for each tree. Type strains of the most closely related Bradyrhizobium spp. on the GenBank sequence database (www.ncbi.nlm. nih.gov/genbank) were included in the 16s rRNA and

Table 1 Bacterial isolates were obtained from Lupinus polyphyllus at four sites at Arthur's Pass (11 isolates: AP1-11), three sites in the Mackenzie Basin (six isolates: MB1-6), two sites in Central Otago (three isolates: $\mathrm{CO} 1-3$ ), and one site near Te Anau (two isolates: TA1-2) in March 2013. Plants were sampled from wild populations except at one agricultural site at Sawdon Station, Lake Tekapo (MB5-6).

\begin{tabular}{ccc}
\hline Isolate & Location & Location co-ordinates \\
\hline AP1-4, 11 & Arthur's Pass & $\mathrm{S} 42^{\circ} 57.720^{\prime}, \mathrm{E} 171^{\circ} 34.521^{\prime}$ \\
AP7-10 & Arthur's Pass & $\mathrm{S} 43^{\circ} 01.049^{\prime}, \mathrm{E} 171^{\circ} 35.624^{\prime}$ \\
AP5 & Arthur's Pass & $\mathrm{S}^{\circ} 03^{\circ} 01.268^{\prime}, \mathrm{E} 171^{\circ} 35.844^{\prime}$ \\
AP6 & Arthur's Pass & $\mathrm{S} 43^{\circ} 16.613^{\prime}, \mathrm{E} 171^{\circ} 42.453^{\prime}$ \\
MB1-2 & Mackenzie Basin & $\mathrm{S}^{\circ} 04^{\circ} 04.838^{\prime}, \mathrm{E} 170^{\circ} 31.945^{\prime}$ \\
MB3-4 & Mackenzie Basin & $\mathrm{S}^{\prime} 4^{\circ} 03.901^{\prime}, \mathrm{E} 170^{\circ} 21.801^{\prime}$ \\
MB5-6 & Mackenzie Basin & $\mathrm{S} 44^{\circ} 03.925^{\prime}, \mathrm{E} 170^{\circ} 29.357^{\prime}$ \\
CO1-2 & Central Otago & $\mathrm{S} 44^{\circ} 30.872^{\prime}, \mathrm{E} 169^{\circ} 49.712^{\prime}$ \\
CO3 & Central Otago & $\mathrm{S} 44^{\circ} 53.561^{\prime}, \mathrm{E} 168^{\circ} 59.600^{\prime}$ \\
TA1-2 & Te Anau & $\mathrm{S} 45^{\circ} 08.185^{\prime}, \mathrm{E} 167^{\circ} 55.802^{\prime}$ \\
\hline
\end{tabular}

nodA trees. Ensifer meliloti was used as an out-group on both trees.

\section{Nodulation and $\mathbf{N}_{2}$ fixation}

All isolates were tested for nodulation and $\mathrm{N}_{2}$ fixation under sterile laboratory conditions. Seeds of $L$. polyphyllus were scarified then surface sterilised in $0.5 \%$ sodium hypochlorite for $15 \mathrm{~min}$, rinsed in deionised water and then germinated on moist germination paper at room temperature in the dark. After germination, seedlings were transferred to polyethylene terephthalate jars (one seedling per jar) containing vermiculite and were supplied with a complete nutrient medium $(\mathrm{pH}$ 6.0) as described previously (Tan et al. 2012). Plants were grown in a controlled environment cabinet and exposed to a 16-h photoperiod (400 $\mu \mathrm{mol}$ photons/ $\mathrm{m}^{2} / \mathrm{s}$ ) at a constant $25^{\circ} \mathrm{C}$. At planting, seedlings were inoculated with $5 \mathrm{ml}$ of the appropriate rhizobial strain grown to $\log$ phase, ca. $1 \times 10^{8} \mathrm{cfu} / \mathrm{ml}$. Uninoculated plants supplied with YMB only were used as controls. There were three replicate jars per treatment. At 40-50 days after inoculation, plants were tested for nitrogenase activity using the acetylene reduction assay (Cummings et al. 2009).

\section{Rhizobial effectiveness}

Eleven isolates, representative of all 22 strains obtained from L. polyphyllus, were tested along with the commercial Group G inoculant for effectiveness on growth of plants in high country soil in a glasshouse. Germinated L. polyphyllus seeds were planted into 1.5 litre pots (two seedlings per pot) containing topsoil from a site at Glenmore Station, Lake Tekapo, with no known history of $L$. polyphyllus or other lupin crops (pH 5.5, Olsen P 14 mg/litre, K 0.69 me/100 g, Mg 0.83 $\mathrm{me} / 100 \mathrm{~g}$, and Al $2.5 \mathrm{mg} / \mathrm{kg}$ ). Plants were inoculated with the appropriate strain at planting and after 24 days. Five replicate pots were used for each strain and an uninoculated control. Pots were watered with tap water when necessary. When seedlings had 2-3 leaves, they were thinned to one per pot. Plants were harvested 79 days after sowing, and symbiotic effectiveness assessed by analysis of variance of dry weights using GenStat 16 software.

\section{Results and Discussion}

At all 10 field sites (Table 1), all L. polyphyllus plants sampled were heavily nodulated. These nodules were pink inside and assumed to be functional. Twenty-two bacterial isolates obtained from these nodules were shown to form functional nodules on L. polyphyllus on inoculation in sterile laboratory conditions (acetylene reduction activity). These results indicate that rhizobia that nodulate $L$. polyphyllus are present across a wide range of sites in the South Island, including 
the agricultural stand of $L$. polyphyllus at Sawdon Station, Lake Tekapo, which was established using uninoculated seed (Black et al. 2014).

The 16s rRNA and nodA gene sequences identified all 22 isolates and the Group G inoculant as Bradyrhizobium spp. One isolate (AP11) showed substantially different 16 s rRNA and $\operatorname{nodA}$ sequences from the others and was not included in the phylogenetic trees (Figure 1). The 16s rRNA sequence for this strain showed $97.5 \%$ similarity to that of $B$. japonicum isolated from the crop plant Glycine max (soya bean) in Japan (Kaneko et al. 2011). Its nodA sequence showed $72 \%$ similarity to that of B. cytisi isolated from Cytisus villosus (hairy broom) in the Moroccan Rif (Chahboune et al. 2011). The origin of this isolate is unclear.

The other 21 isolates from L. polyphyllus clustered together for both $16 \mathrm{~s}$ rRNA (Figure 1A) and nodA (Figure 1B) gene sequences. The $16 \mathrm{~s}$ rRNA sequences separated into four groups. Groups 1 and 2 (11 isolates) were most closely related to $B$. canariense (99.58\%-99.75\% similarity) which was isolated from Chamaecytisus palmensis (tree lucerne) in La Laguna (Tenerife), Spain (Vinuesa et al. 2005) and to the Group $\mathrm{G}$ inoculant (99.00\%-99.17\% similarity). Groups 3 and 4 were most closely related to $B$. japonicum (99.57\%-99.83\% similarity). The nodA sequences separated into two major groupings. Two of the strains aligned closest to the isolate from the Group $G$ inoculum, but 19 of the strains clustered together closest to, but clearly separate from $(92.89 \%-$ $96.67 \%$ similarity), B. cytisi isolated from $C$. villosus.

Thus overall, the DNA sequence data indicate that
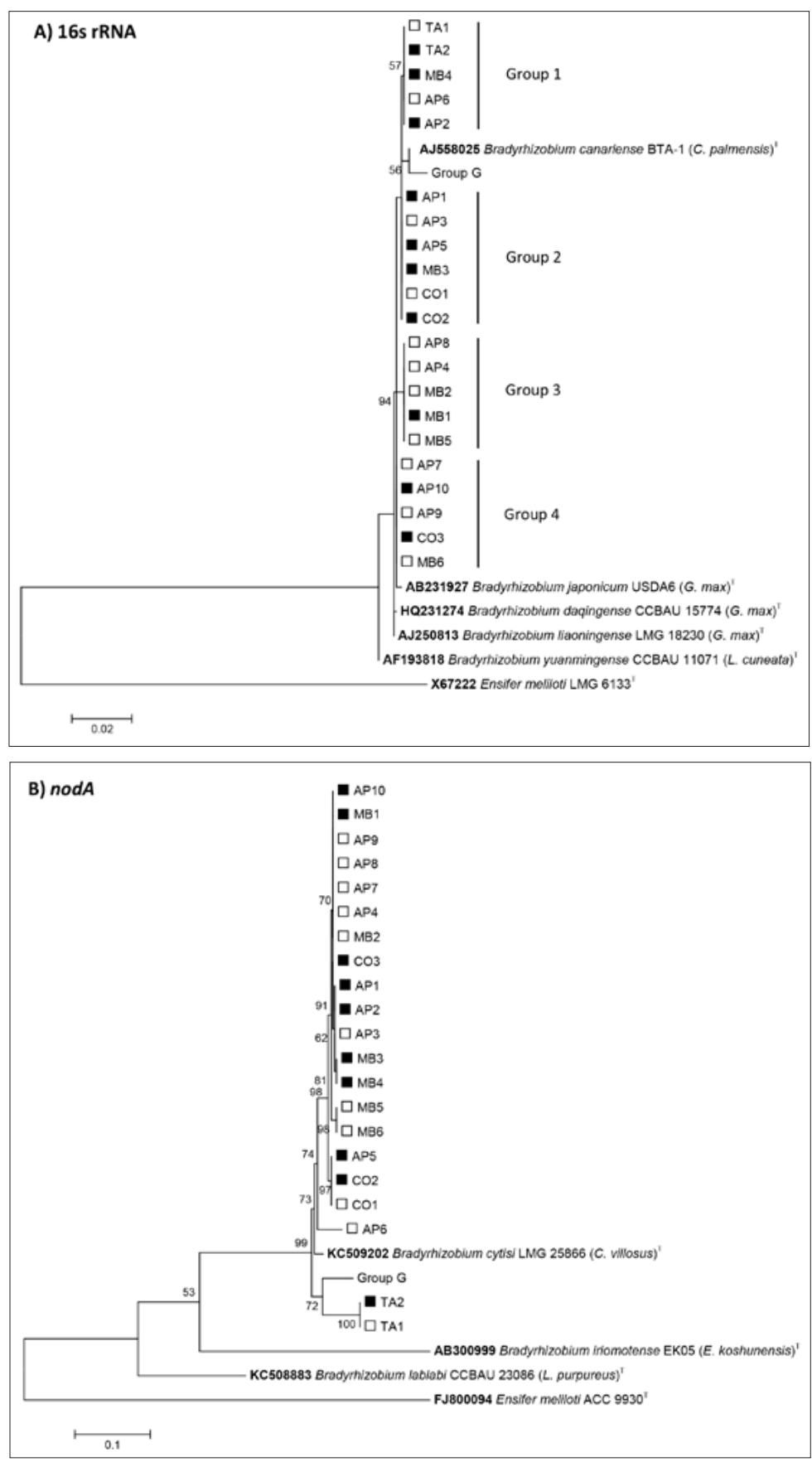

Figure 1 Phylogenetic genetic trees of $16 \mathrm{~s}$ rRNA (A) and nodA (B) gene sequences of 21 bacterial isolates from Lupinus polyphyllus sampled in soils at Arthur's Pass (AP1-10), Mackenzie Basin (MB1-6), Central Otago (CO1-3) and Te Anau (TA1-2) in New Zealand, commercial Group G inoculant currently recommended for use on annual lupins, and selected type strains ( ${ }^{\top}$ ) of Bradyrhizobium spp. GenBank accession numbers are in bold and host legume species are in parentheses. Ensifer meliloti was used as an outgroup. Selected isolates (口) were tested in a glasshouse experiment. Numbers on branches indicate bootstrap \% from 500 replicates (shown only when $\geq 50 \%$ ). 


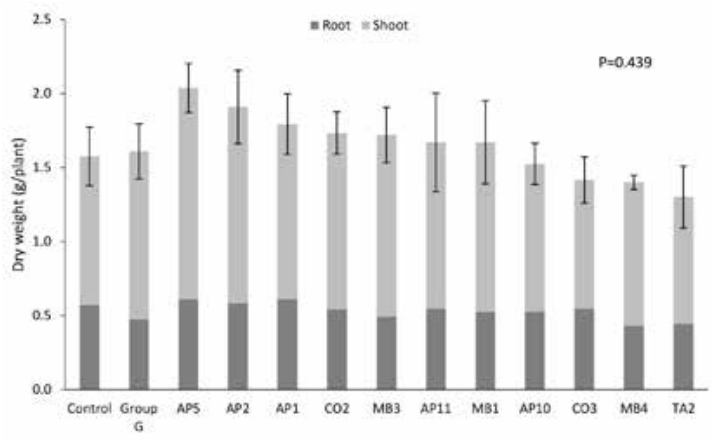

Figure 2 Dry weight of Lupinus polyphyllus plants inoculated with 11 bacterial isolates from $L$. polyphyllus sampled in soils at Arthur's Pass (AP), Mackenzie Basin (MB), Central Otago (CO) and Te Anau (TA) in New Zealand, an isolate from a commercial Group G inoculant currently recommended for use on annual lupins, and an uninoculated control, in high country soil collected from an agricultural site at Glenmore Station, Lake Tekapo. Standard errors of means and the level of significance for total plant dry weight are given.

bradyrhizobia with distinct nodA genes are of widespread occurrence in the South Island of New Zealand. The possible sources of these bradyrhizobia are: 1) an inoculant used in New Zealand in the past, 2) a strain from outside New Zealand that has become established with $L$. polyphyllus throughout the South Island, and 3) naturally occurring bradyrhizobia in New Zealand that nodulate L. polyphyllus. Further work is required to clarify this point.

In the glasshouse experiment, all L. polyphyllus plants were nodulated regardless of inoculum treatment. This result is in agreement with the field study and indicates that rhizobia that nodulate L. polyphyllus were present in the agricultural soil tested from Glenmore Station, Lake Tekapo, with no known history of L. polyphyllus or other lupin crops. It is also in agreement with Scott (1989), who stated that L. polyphyllus will nodulate in high country soils without inoculum, although it was also indicated that use of rhizobial inoculum could be beneficial. In the glasshouse experiment, there was variability in total plant dry weight across the inoculum treatments (Figure 2). In particular, growth with strain AP5 appeared to be greater than that of the control, indicating that there may be potential for selection of an elite strain for use as a rhizobial inoculum. However, this experiment needs to be repeated and carried out for a longer time period before recommendations could be made with regard to use of inoculum on L. polyphyllus in high country soils.

\section{ACKNOWLEDGEMENTS}

The authors are grateful for the NZ Merino Company Ltd, Struthers Trust, Sinclair Cummings Trust and
Alexander Agribusiness scholarships received by RyanSalter, and support from the Brian Mason Scientific and Technical Trust.

\section{REFERENCES}

Andrews, M.; James, E.K.; Sprent, J.I.; Boddey, R.M.; Gross, E.; dos Reis Jr, F.B. 2011. Nitrogen fixation in legumes and actinorhizal plants in natural ecosystems: values obtained using $15 \mathrm{~N}$ natural abundance. Plant Ecology \& Diversity 4: 131-140.

Andrews, M.; Raven, J.A.; Lea, P.J. 2013. Do plants need nitrate? The mechanisms by which nitrogen form affects plants. Annals of Applied Biology 163: 174-199.

Black, A.D.; Loxton, G.; Ryan-Salter, T.P.; Moot, D.J. 2014. Sheep performance on perennial lupins over three years at Sawdon Station, Lake Tekapo. Proceedings of the New Zealand Grassland Association 76: 35-39.

Chahboune, R.; Carro, L.; Peix, A.; Barrijal, S.; Velázquez, E.; Bedmar, E.J. 2011. Bradyrhizobium cytisi sp. nov., isolated from effective nodules of Cytisus villosus. International Journal of Systematic and Evolutionary Microbiology 61: 2922-2927.

Chaintreuil, C.; Boivin, C.; Dreyfus, B.; Giraud, E. 2001. Characterization of the common nodulation genes of the photosynthetic Bradyrhizobium sp. ORS285 reveals the presence of a new insertion sequence upstream of nodA. FEMS Microbiology Letters 194: 83-86.

Cummings, S.P.; Gyaneshwar, P.; Vineusa, P.; Farruggia, F.T.; Andrews, M.; Humphry, D.; Elliot, G.N.; Nelson, A.; Orr, C.; Pettitt, D.; Shah, G.R.; Santos, S.R.; Krishnan, H.B.; Odee, D.; Moreira, F.M.S.; Sprent, J.I.; Young, J.P.W.; James, E.K. 2009. Nodulation of Sesbania species by Rhizobium (Agrobacterium) strain IRBG74 and other rhizobia. Environmental Microbiology 11: 2510-2525.

Jarabo-Lorenzo, A.; Perez-Galdona, R.; DonateCorrea, J.; Rivas, R.; Velazquez, E.; Hernandez, M.; Temprano, F.; Martinez-Molina, E.; Ruiz-Argueso, T.; Leon-Barrios, M. 2003. Genetic diversity of bradyrhizobial populations from diverse geographic origins that nodulate Lupinus spp. and Ornithopus spp. Systematic and Applied Microbiology 26: 611623.

Kaneko, T.; Maita, H.; Hirakawa, H.; Uchiike, N.; Minamisawa, K.; Watanabe, A.; Sato, S. 2011. Complete genome sequence of the soybean symbiont Bradyrhizobium japonicum strain USDA6T. Genes 2: 763-787.

Scott, D. 1989. Perennial or Russell lupin: a potential high country pasture legume. Proceedings of the New Zealand Grassland Association 50: 203-206. 
Scott, D. 2014. The rise to dominance of Lupinus polyphyllus among pasture mixtures in tussock grassland trials. Proceedings of the New Zealand Grassland Association 76: 47-52.

Tamura, K.; Dudley, J.; Nei, M.; Kumar, S. 2007. MEGA4: molecular evolutionary genetics analysis (MEGA) software version 4.0. Molecular Biology and Evolution 24: 1596-1599.

Tan, H.W.; Weir, B.S.; Carter, N.; Heenan, P.B.; Ridgway, H.J.; James, E.K.; Sprent, J.I.; Young, J.P.W.; Andrews, M. 2012. Rhizobia with 16S rRNA and nifH similar to Mesorhizobium huakuii but novel recA, glnll, nodA and nodC genes are symbionts of New Zealand Carmichaelinae. PLoS One 7: e47677.

Vincent, J.M. 1970. A manual for the practical study of the root-nodule bacteria. IBP handbook 15 . Blackwell Scientific, Oxford and Edinburgh. 164 pp.

Vinuesa, P.; León-Barrios, M.; Silva, C.; Willems, A.; Jarabo-Lorenzo, A.; Pérez-Galdona, R.; Werner, D.;
Martínez-Romero, E. 2005. Bradyrhizobium canariense sp. nov., an acid-tolerant endosymbiont that nodulates endemic genistoid legumes (Papilionoideae: Genisteae) from the Canary Islands, along with Bradyrhizobium japonicum bv. genistearum, Bradyrhizobium genospecies alpha and Bradyrhizobium genospecies beta. International Journal of Systematic and Evolutionary Microbiology 55: 569-575.

Weir, B.S.; Turner, S.J.; Silvester, W.B.; Park, D.; Young, J.M. 2004. Unexpectedly diverse Mesorhizobium strains and Rhizobium leguminosarum nodulate native legume genera of New Zealand, while introduced legume weeds are nodulated by Bradyrhizobium species. Applied and Environmental Microbiology 70: 5980-5987.

Weisburg, W.G.; Barns, S.M.; Pelletier, D.A.; Lane, D.J. 1991. 16S ribosomal DNA amplification for phylogenetic study. Journal of Bacteriology 173: 697-703. 